\title{
Herbicide savings and economic benefits of several strategies to control Sorghum halepense in maize crops
}

\author{
D. Andújar ${ }^{\mathrm{a}, 1}$, A. Ribeiro ${ }^{\mathrm{b}}, \mathrm{C}$. Fernández-Quintanilla ${ }^{\mathrm{a}}$, J. Dorado ${ }^{\mathrm{a}, *}$ \\ a Instituto de Ciencias Agrarias, CSIC, Serrano 115B, 28006 Madrid, Spain \\ ${ }^{\mathrm{b}}$ Centro de Automática y Robótica, CSIC-UPM, 28500 Arganda del Rey, Madrid, Spain
}

\section{A R T I C L E I N F O}

\section{Article history:}

Received 31 October 2012

Received in revised form

2 April 2013

Accepted 3 April 2013

\section{Keywords:}

Site-specific weed management

Net returns

Weed patches

Herbicide rates

Buffer zones

\begin{abstract}
A B S T R A C T
This study was conducted to assess the herbicide savings and the cost efficiency of site-specific herbicide application strategies in comparison with other strategies based on uniform application of herbicides throughout the whole field. The specific situation considered was Sorghum halepense infested maize fields in Spain. The results from a theoretical economic model were contrasted with the information derived from a $S$. halepense survey conducted in 37 commercial maize fields distributed over three Spanish maize production areas. Seven application strategies were simulated: 1) no herbicide; 2) overall full-rate; 3) overall half-rate; 4) and 5) site-specific spraying infested cells with full- and half-rate, respectively; 6) and 7) site-specific spraying infested cells plus adjacent buffer areas with full- and half-rate, respectively. The simulation results showed that site-specific weed management was the most profitable strategy when $S$. halepense infested area ranged between 6.5 and $18.7 \%$. This scenario was present in $22 \%$ of the surveyed fields. In fields with less than $6.5 \%$ infestation (a situation present in $51 \%$ of the surveyed fields), yield losses were slight and the most profitable strategy was using no herbicide. When the infested area ranged between 18.7 and $40.8 \%$ (19\% of the surveyed fields), no significant differences were observed between the net benefits of the various strategies. Full rate herbicide applications throughout the entire field resulted in the highest net returns in fields with more than $40.8 \%$ weed infestation ( $8 \%$ of the surveyed fields). In these cases, the added costs of weed detection, mapping and site-specific herbicide application were not justified by the herbicide savings obtained. Likewise, herbicide savings obtained with the various strategies depended on the proportion of the field infested. Considering the high difference between site-specific treatments and uniform application of herbicides when the infested area ranged between 18.7 and $40.8 \%$, and that no significant differences in net returns were observed in this range, site-specific treatments should be preferred. Adding a buffer area to the sitespecific treatments does not seem a suitable strategy due to the considerable increases in costs and reductions in herbicide savings.
\end{abstract}

(c) 2013 Elsevier Ltd. All rights reserved.

\section{Introduction}

Weed populations are irregularly distributed within agricultural fields. This heterogeneity can be managed by applying herbicides exclusively where weed density is above an economic threshold (Weis et al., 2008) or by adjusting herbicide rates for actual weed densities. Although site-specific weed management has been proved to be technically feasible and to yield substantial reductions in herbicide use (Gerhards and Oebel, 2006; Nordmeyer, 2006;

\footnotetext{
* Corresponding author. Tel.: +34 917452500.

E-mail address: jose.dorado@ica.csic.es (J. Dorado).

1 Present address: University of Hohenheim, Department of Weed Science, OttoSander-Straße 5, 70599 Stuttgart, Germany.
}

Timmermann et al., 2003; Young et al., 2003), the high technological costs associated with these technologies may preclude their adoption by farmers (López-Granados, 2011; Rider et al., 2006). In this regard, the basic question is whether the added costs of using patch spraying technologies are more than compensated by the benefits of doing so (Swinton, 2005).

According to Swinton (2005), the evidence of market-based profitability of site-specific weed management looks highly questionable due to the lack of significant information on costs for scouting, making treatment maps and patch herbicide application. A limited number of analyses have already considered these factors. Simulation studies conducted for Avena sterilis L. (sterile oat) infesting winter barley fields in Spain have concluded that technology costs are the parameter with greatest influence on the profitability of site-specific weed management (Barroso et al., 
2004). Considering the low levels of $A$. sterilis infestation generally present in Spanish barley fields and the low economic returns of this crop under semi-arid conditions, the most profitable management strategy was generally no herbicide application (Ruiz et al., 2006). However, in areas with a higher yield potential, sitespecific herbicide application was found to be superior from the economic standpoint than uniform label-rate or half-rate applications.

Sorghum halepense (L.) Pers. (johnsongrass) is one of the most serious weeds in maize in Spain (Taberner, 2006). This weed is extremely competitive with maize, reducing yields up to $100 \%$ (Barroso et al., 2011). Due to its vegetative reproduction system, this species has a tendency to grow in compact patches which are easy to detect early in the season and at harvest time. A detailed survey conducted at harvest on commercial maize fields provided a valuable data set on the spatial distribution pattern of $S$. halepense on Spanish maize crops (Andújar et al., 2011b). The main objective of this study was to assess the economic benefits and the herbicide savings of using site-specific weed management for this species in comparison with management strategies based on uniform application of herbicides throughout the whole field.

\section{Materials and methods}

\subsection{Economic analysis and herbicide savings}

A theoretical model was developed to assess the profitability and potential herbicide savings resulting from different management strategies for $S$. halepense in maize crops. Seven herbicide application strategies were simulated. Three of the strategies did not require the use of precision agriculture technologies: 1) no herbicide application; 2) overall full-rate herbicide application; and 3) overall half-rate herbicide application. Two strategies were based on standard site-specific weed management: 4) full-rate herbicide application to infested cells recorded in the map; and 5) half-rate herbicide application to infested cells of the treatment map. The other two strategies were also site-specific but included buffer zones: 6) full-rate herbicide application to infested cells recorded in the map and to adjacent cells; and, 7) half-rate herbicide application to infested cells of the treatment map and to adjacent cells.

The economic analysis for each weed control strategy was performed with a modified model from that proposed by Andújar et al. (2011a), according to the following equation:

$$
\begin{aligned}
\mathrm{NR}^{S}= & \hat{y} \\
& -\left(1-L^{0} \frac{\sum_{k=1}^{n} I_{k}}{n}+\left(L^{0}-L^{s}\right) \frac{\sum_{k=1}^{n} d_{k}^{S} I_{k}}{n}\right) p \\
& \left(C_{\mathrm{a}}^{S}+H^{s} \frac{\sum_{k=1}^{n} d_{k}^{S}}{n}+C_{o}\right)
\end{aligned}
$$

where NR is the net return in $€$ per hectare and the superscript $s$ denotes the herbicide application strategy; $\hat{y}$ the maize yield in an area free of $S$. halepense (estimated at $12,000 \mathrm{~kg} \mathrm{ha}^{-1}$, from the work of Barroso et al., 2011); $k$ is the current cell; $n$ the total number of infested cells; $L^{0}$ is the yield loss estimated in infested cells with no herbicide application [29.53\% for non-treated cells, according to the relationship between weed density and maize yield reported by Barroso et al. (2011), considering an average weed density of 8 plants $\mathrm{m}^{-2}$ ] and $L^{s}$ is the yield loss estimated in infested cells according to the application rate for scenario $s$ [11.32\% for cells treated at half-rate and $6.56 \%$ for cells treated at full-rate, according to the relationship between weed density and maize yield reported by Barroso et al. (2011), considering a residual weed population after treatment of 3 and 1.5 plants $\mathrm{m}^{-2}$, respectively]; $p$ the maize grain price $\left[0.21 € \mathrm{~kg}^{-1}\right.$. Quoted price in August 2012 at the market of Albacete (http://www.itap.es/ITAP-Comun/Novedades/ Documentos/BOLETIN\%20AGOSTO\%202012.pdf)]; $C_{\mathrm{m}}^{\mathrm{s}}$ the cost of mapping the weeds of the field from the combine [only considered in site-specific treatments: $9 € \mathrm{ha}^{-1}$ (Ruiz et al., 2006. According to Dr Ruiz, these costs have not changed substantially in recent years)]; $C_{\mathrm{a}}^{\mathrm{s}}$ the treatment cost with a sprayer $\left[6.61 € \mathrm{ha}^{-1}\right.$, plus $4.5 € \mathrm{ha}^{-1}$ when herbicide is applied site-specifically (Barroso et al., 2004. According to Dr Barroso, these costs have not changed substantially in recent years)]; $H^{s}$ is the herbicide (rimsulfuron) cost for strategy $s ; I_{k}$ is an indicator variable equal to 1 if cell $k$ is infested and 0 otherwise, and $d_{k}^{s}$ is an indicator variable equal to 1 if site $k$ is treated with a herbicide in strategy $s$ and 0 otherwise $\left(H^{s}\right.$ is estimated as $90 € \mathrm{ha}^{-1}$ for a full rate treatment, i.e., when $I_{k}=1$ and $d_{k}^{S}=1$ ); and $C_{o}$ the rest of the costs for maize cropping such as tillage, fertilizers, seeding, pre-emergence herbicide, irrigation, etc. (estimated as $900 € \mathrm{ha}^{-1}$ ).

This equation suggests that net returns to a particular strategy depends on the proportion of the field infested with weeds $\left(\sum_{k=1}^{n} I_{k} / n\right)$, the proportion of the field treated with a herbicide $\left(\sum_{k=1}^{n} d_{k}^{s} / n\right)$, and the proportion of the field infested with $S$. halepense and treated with herbicide $\left(\sum_{k=1}^{n} d_{k}^{S} I_{k} / n\right)$. Hence, the strategy $s$ will be more profitable than $s^{\prime}$ when $\mathrm{NR}^{s}>\mathrm{NR}^{s^{\prime}}$, a relationship that can be compared by the following function:

$$
\begin{gathered}
p \widehat{y} L^{0}\left(\frac{\sum_{k=1}^{n} d_{k}^{s} I_{k}}{n}-\frac{\sum_{k=1}^{n} d_{k}^{s^{\prime}} I_{k}}{n}\right)+p \widehat{y}\left(L^{s^{\prime}} \frac{\sum_{k=1}^{n} d_{k}^{s^{\prime} I_{k}}}{n}-L^{s} \frac{\sum_{k=1}^{n} d_{k}^{S} I_{k}}{n}\right) \\
+\left(C_{\mathrm{m}}^{s^{\prime}}-C_{\mathrm{m}}^{s}\right)+\left(C_{\mathrm{a}}^{s^{\prime}}-C_{\mathrm{a}}^{s}\right)+H^{s^{\prime}} \frac{\sum_{k=1}^{n} d_{k}^{s^{\prime}}}{n}-H^{s} \frac{\sum_{k=1}^{n} d_{k}^{s}}{n}>0
\end{gathered}
$$

Consequently, real data from commercial maize fields infested with $S$. halepense would be desirable to assess the economic benefits and herbicide savings according to the theoretical model proposed. Therefore, this study has used a collection of data from different fields with different levels of infestation of S. halepense, as explained below. One-way analysis of variance (ANOVA) with Scheffe's multiple comparisons post hoc test was performed to test the mean net returns as well as the mean herbicide savings of different herbicide application strategies within the response ranges according to the percentage of weed infestation.

\subsection{Field sites and weed mapping}

Thirty seven fields were evaluated at harvest time in 2007 and 2008 , with a total sampling area of 230 ha, which were used to know the real infestation percentages of $S$. halepense and its distribution within the field. These data were used to compare different control strategies according to the proposed model.

S. halepense spatial distribution was sampled on 37 commercial maize fields located in three different Spanish provinces: Badajoz (south west), Madrid (centre) and Albacete (south east). The field size was characterized by a distribution ranging from 2.0 ha (25th percentile), 3.4 ha (median) and 7.0 ha (75th percentile), with extreme values ranging from 0.4 to 44.0 ha. There were large environmental and agronomic differences between regions, details being previously explained in the article by Andújar et al. (2011b). Other characteristics such as flat topography, low natural soil fertility and the use of high input levels in terms of supply of fertilizers and water remained similar between regions.

S. halepense infestations were visually assessed from the combine cabin at harvest time by an observer who was always the same person and previously trained in weed mapping in order to minimize the sampling errors. Detailed information about the 
survey methodology is available in Andújar et al. (2011b). Infested areas were easily identified because of the difference in colour between $S$. halepense, which remained green, and maize, which was completely dry. S. halepense patches were relatively homogeneous, being identified as infested area when weed presence was detected, creating a binary data base of presence/absence. S. halepense infestation was mapped continuously using a system consisting of a differential geo-positioning system (DGPS) receiver (Hemisphere Crescent R130, Hemisphere GPS, Calgary, AB, Canada) with Omnistar differential correction, a Tablet PC (Itronix Duo-Touch ${ }^{\mathrm{TM}}$ Tablet PC, General Dynamics, Sawgrass Corporate Parkway, FL, USA) and a specific software written in visual basic for this application able to merge the DGPS co-ordinates and the information of presence/absence selected by the observer. A conventional 6-row harvester working at a speed of $4-4.5 \mathrm{~km} \mathrm{~h}^{-1}$ was used, so that the width of each transect was $4.2 \mathrm{~m}$ and the distance between points within the same transect was approximately $1.1-1.25 \mathrm{~m}$.
Spatial data management was carried out using $\operatorname{ArcGis}{ }^{\circledR} 9.3$ (ESRI, Redlands, California, USA). A $4 \times 4 \mathrm{~m}$ grid of treatment cells was constructed for each field, which corresponds to a $4 \mathrm{~m}$ section of a sprayer boom. Indicator kriging was used because of the binary nature (weed presence/absence) of the data. The data values were transformed to a series of $0 \mathrm{~s}$ and $1 \mathrm{~s}$ according to whether the probability values in each treatment cell were below or above a threshold. Those treatments cells with a probability value below 0.5 were assigned a value of 0 , whereas the values above 0.5 were assigned a value of 1 and therefore were considered as suitable for herbicide treatment. Indicator kriging then used a semivariogram model that was calculated from the transformed 0-1 dataset (Johnston, 2004). The possible addition of security zones ("buffers") to infested cells was also explored. The creation of these "more secure" maps was made by selection of adjacent cells [the size of buffer zone was adjusted to the $4 \times 4 \mathrm{~m}$ grid, which was conditioned by the spray bar section, i.e., the minimum possible
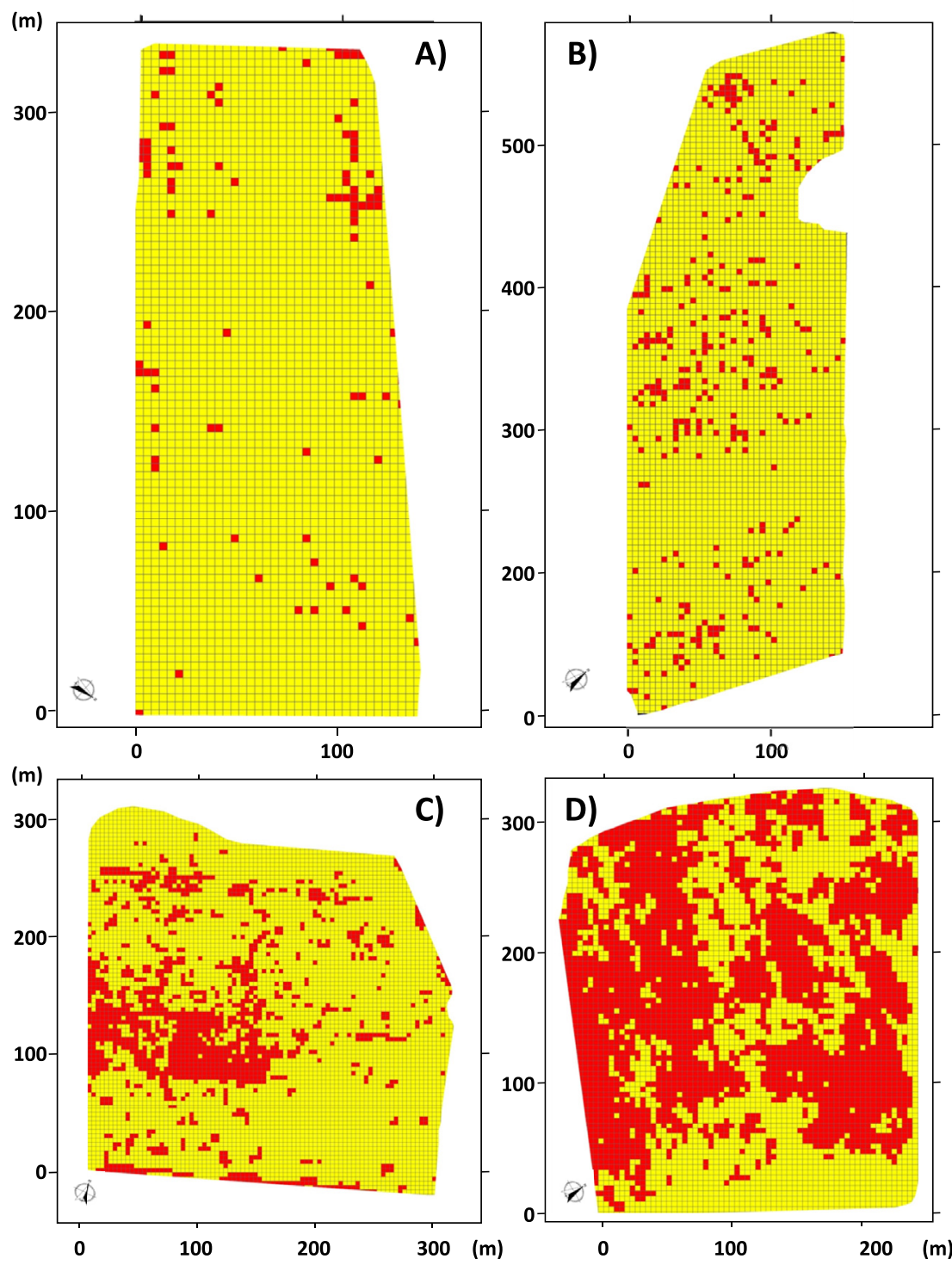

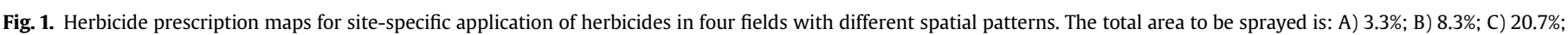

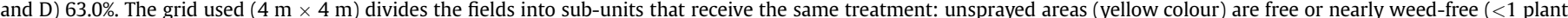

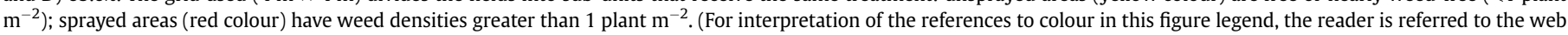
version of this article.) 
dimension but sufficient to account for lead and lag times of the sprayer (Lutman and Miller, 2007)] to those with a value higher than 0.5 in the interpolated map and the subsequent conversion to suitability for herbicide spraying cells. These buffer zones were intended to encompass both the possible errors in the detection procedure and the possible expansion of patches from the mapping time (autumn) to the herbicide treatment in the following season.

\section{Results}

The spatial distribution of $S$. halepense in maize fields may be very variable, with infestation levels of the surveyed fields ranging from 1.0 to $88.3 \%$ of the total area (data not shown). Consequently, the proportion of fields to be sprayed site-specifically may range considerably. Fig. 1 illustrates the prescription maps for site-specific application of herbicides in four fields with contrasting spatial patterns. In these four examples, the total area to be sprayed ranged from 3 to $63 \%$.

According to our simulations, the best management strategy from an economic point of view depended on the level of infestation present in the field. Fig. 2 shows the net returns of five management strategies according to the model proposed. In fields with a very low proportion of infested areas $(<6.5 \%)$, the most profitable strategy was no herbicide application $(P<0.001$ in the ANOVA analysis). This was the most common pattern in the mapped fields (i.e., 19 fields from a total of 37 field sampled, or $51 \%$ of total samples). When more than $6.5 \%$ of the field was infested by $S$. halepense, expected crop yield losses caused by this weed always justified the cost of herbicide application. When the infested areas ranged between 6.5 and $18.7 \%$, the most profitable strategy was patch spraying $(P=0.001$ in the ANOVA analysis). These levels of infestation were found in $22 \%$ of the analysed fields (i.e., 8 fields from a total of 37 field sampled). When the infested area ranged between 18.7 and $40.8 \%$, the least profitable strategy was no herbicide application $(P<0.001$ in the ANOVA analysis), while no significant differences were observed between herbicide application strategies. When more than $40.8 \%$ of the field was infested, full rate herbicide application throughout the entire field resulted in the highest net returns ( $P=0.043$ in the ANOVA analysis). Actual number of fields with more than $40.8 \%$ of the area infested by S. halepense represented only $8 \%$ of the field samples (i.e., 3 fields from a total of 37 field sampled).

Using additional buffer zones reduced the economic returns of site-specific treatments in all cases, regardless of the level of infestation of $S$. halepense and the rate of herbicides. Adding buffer zones increased the sprayed area in inverse proportion to the percentage of infestation of $S$. halepense. On average, there was a 3.5-fold increase in the surface to be sprayed in fields with less than $18.7 \%$ weed infestation, an increase ranging between 3.5 and 2 times in fields with weed infestations between 18.7 and $40.8 \%$ respectively, and about 1.2 -fold increase in fields with more than $40.8 \%$ weed infestation (data not shown). Obviously, the distribution of the patches conditions the increase of the area sprayed due to the addition of buffers. This is exemplified in Fig. 3, where two fields with a similar proportion of weed infestation but different distribution patterns resulted in different increments of the area sprayed when buffers were applied. Due to the high cost of specific herbicides for $S$. halepense, such a significant increase in the surface to be sprayed does not justify the use of buffer zones. The inclusion of these zones is a conservative strategy to ensure weed control in those cases in which the infested areas detected at the end of the previous season do not exactly match the infested areas present in the following season.

Apart from the economic information provided by the model, herbicide saving is a key factor to select the best management strategy. Similar to the economic analysis, herbicide savings depended on the proportion of the field infested. Obviously, avoiding herbicide application in fields with very low proportion of infested area would save $100 \%$ of herbicide, half-rate uniform applications would save $50 \%$ of herbicide, and spraying the whole field when the area infested is very large would result in no herbicide savings. Patch spraying fields with low infestation levels (6.5-18.7\%) with full-rate of herbicides would result in herbicide savings ranging from 81.3 to $93.5 \%$.

The herbicide savings of each strategy with respect to uniform application of the full-label herbicide rate to the entire field,

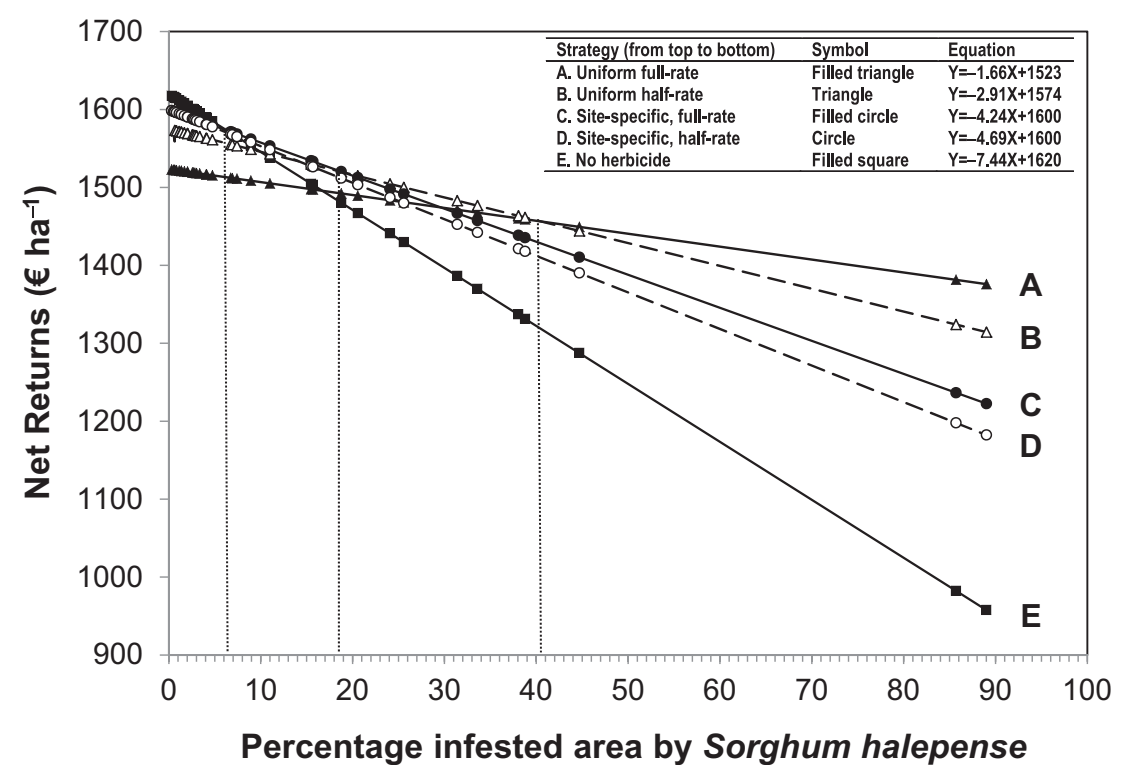

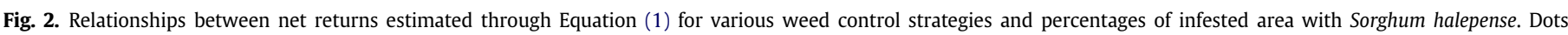

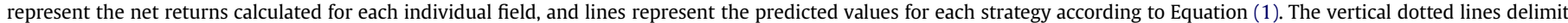

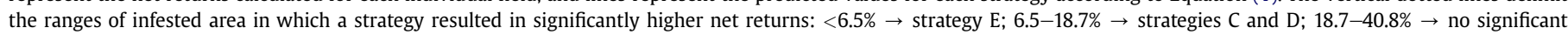
differences; $>40.8 \% \rightarrow$ strategy A. 
A)
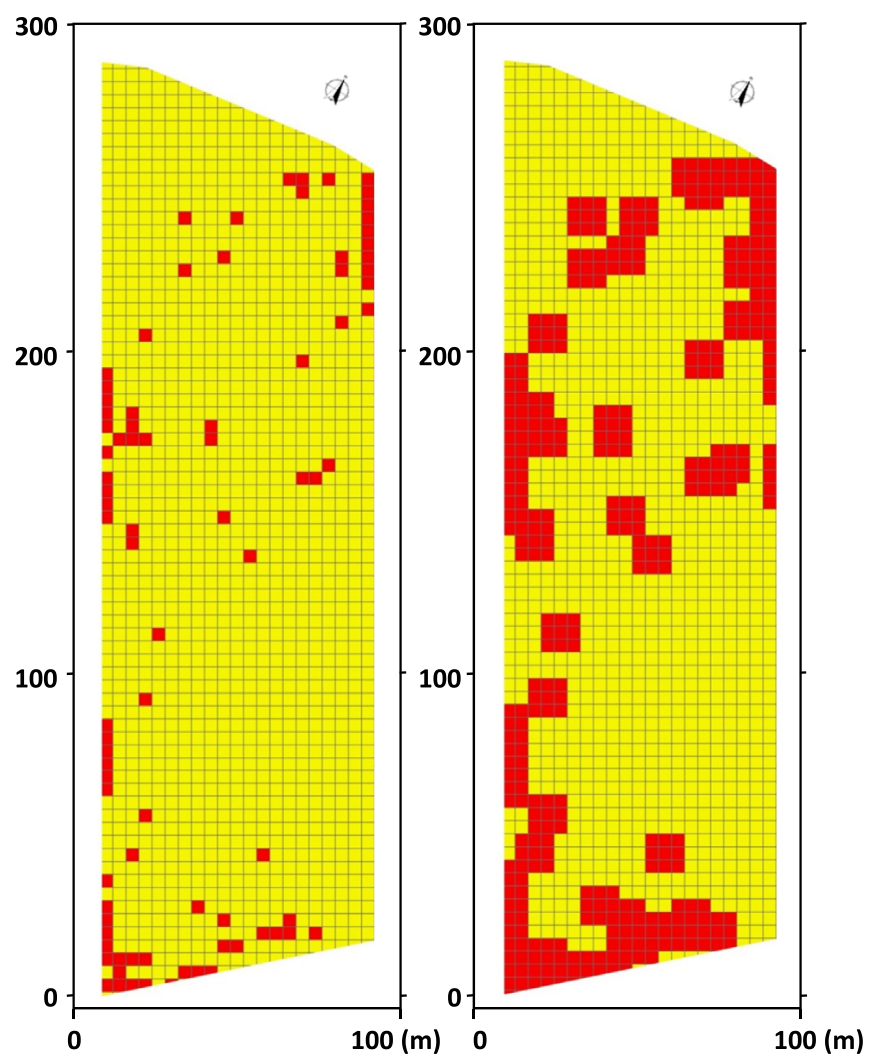
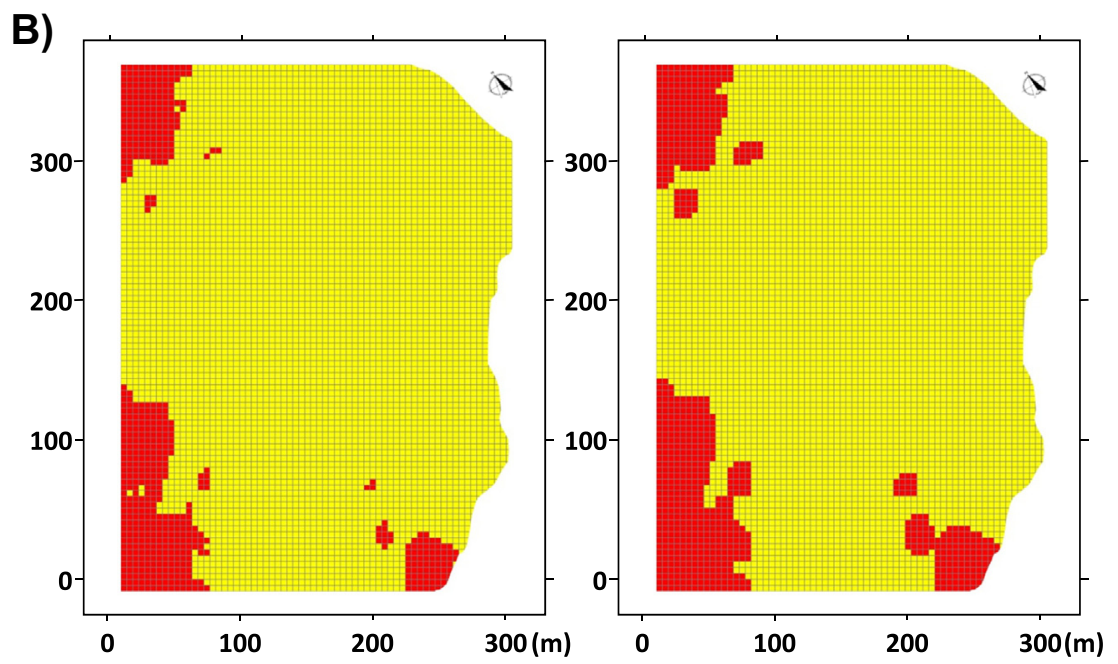

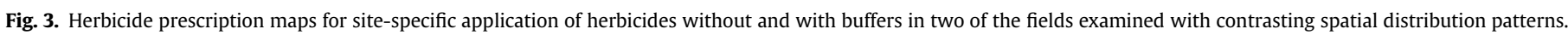

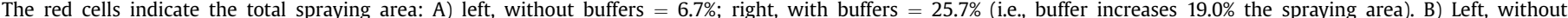

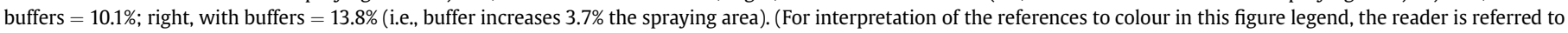
the web version of this article.)

calculated for the 37 surveyed fields, are shown in Table 1 . It is worth noting the higher herbicide saving obtained by site-specific treatments compared to those obtained with the uniform halfrate strategy, when the infested area ranges between 18.7 and $40.8 \%(P<0.001$ in the ANOVA analysis $)$.

\section{Discussion}

Swinton (2005) indicated that most studies assessing sitespecific herbicide-based weed management failed to account for the added costs of using new detection and application technologies. This study provided detailed information on the costs and benefits derived from using this approach in the specific case of $S$. halepense in maize crops in Spain, assessing a variety of control strategies and weed infestation conditions. The model used to make this analysis could be used in other situations (crops/weeds/ geographies), allowing to determine the best management strategy when comparing the site-specific spraying and the traditional herbicide application over the entire surface. According to our results, in fields slightly infested $(<6.5 \%)$ by $S$. halepense, only small yield losses could be prevented by herbicide treatments. Therefore, it was not justified economically to invest in herbicides and/or 
Table 1

Percentages of herbicide savings for each spraying strategy with respect to uniform application of the full herbicide rate to the whole field, calculated for 37 maize fields with different percentage of weed infestation.

\begin{tabular}{|c|c|c|c|c|}
\hline \multirow[t]{2}{*}{ Spraying strategy } & \multicolumn{4}{|c|}{ Percentage infested area by Sorghum halepense } \\
\hline & $<6.5 \%$ & $6.5-18.7 \%$ & $18.7-40.8 \%$ & $>40.8 \%$ \\
\hline Uniform, full-rate (control) & $0.0 e^{a}$ & $0.0 \mathrm{f}$ & $0.0 \mathrm{e}$ & $0.0 \mathrm{~d}$ \\
\hline Uniform, half-rate & $50.0 \mathrm{~d}$ & $50.0 \mathrm{e}$ & $50.0 \mathrm{~d}$ & $50.0 \mathrm{bc}$ \\
\hline Site-specific, full-rate & $97.9 \mathrm{ab}$ & 89.7 bc & $71.2 \mathrm{c}$ & 26.9 bcd \\
\hline $\begin{array}{l}\text { Site-specific with buffer, } \\
\text { full-rate }\end{array}$ & $91.3 \mathrm{c}$ & $73.3 \mathrm{~d}$ & $50.9 \mathrm{~d}$ & $12.5 \mathrm{~cd}$ \\
\hline Site-specific half-rate & $99.0 \mathrm{ab}$ & $94.9 \mathrm{ab}$ & $85.6 \mathrm{~b}$ & $63.4 \mathrm{ab}$ \\
\hline $\begin{array}{l}\text { Site-specific with buffer, } \\
\text { half-rate }\end{array}$ & $95.7 \mathrm{~b}$ & $86.6 \mathrm{c}$ & $75.4 \mathrm{bc}$ & $56.3 \mathrm{abc}$ \\
\hline No herbicide & $100.0 \mathrm{a}$ & $100.0 \mathrm{a}$ & $100.0 \mathrm{a}$ & $100.0 \mathrm{a}$ \\
\hline \multicolumn{5}{|l|}{ Distribution of field size: } \\
\hline $\begin{array}{l}\text { Total number of fields } \\
\text { sampled }\end{array}$ & 19 & 8 & 7 & 3 \\
\hline $\begin{array}{l}\text { Percentiles (ha): } \\
\text { 25\%/median/75\% }\end{array}$ & $1.5 / 4.0 / 7.0$ & $0.8 / 2.8 / 4.3$ & $2.2 / 2.9 / 6.9$ & 4.9/6.9/7.7 \\
\hline Mean size (ha) & 7.7 & 3.5 & 5.2 & 6.1 \\
\hline Size range (ha) & $0.5-44.0$ & $0.4-11.1$ & $0.7-17.3$ & $3.0-8.5$ \\
\hline
\end{tabular}

a Means followed by the same letter in a row are not significantly different $(P<0.05)$ as determined by Scheffe's multiple comparison test.

technology. A similar conclusion has been reached in other studies challenging the usefulness of high cost herbicides on low levels of infestation (Ruiz et al., 2006; Van Wychen et al., 2002). However, this strategy could increase the risk of infestations in the following years. This risk is particularly relevant in the case of maize monoculture, where poor weed control would favour the spread of patches in successive years.

Fields with a significant S. halepense infested area (6.5-18.7\%) may be suitable for site-specific spraying. This strategy resulted in the highest net returns and reduced considerably the amount of herbicide applied. This reduction justified economically the cost of weed detection and mapping and the use of specific technologies for patch spraying. These results are in agreement with previous studies indicating that site-specific weed management reduced the costs for weed control by $8 € /$ ha for maize, mainly due to savings of grass weed herbicides (Gerhards and Sokefeld, 2003). In the study by Gerhards and Christensen (2003), herbicide use with a mapbased approach was reduced in maize by $78 \%$ for grass weeds, thus giving environmental and economic benefits. Similarly, research conducted by Ruiz et al. (2006) with A. sterilis in barley crops showed that site-specific weed management techniques were generally more profitable than uniform spraying. Barroso et al. (2004), working also with this weed species, showed that patch spraying was more profitable on fields with a relatively low proportion of infested areas. Similarly, Jordan et al. (2003) found that site-specific weed management increased theoretical net returns peanut crops in North Carolina.

Although the uniform application of herbicide was slightly more profitable in fields with medium infestations (18.7-40.8\%), this range may raise questions from an environmental point of view. Indeed, the average margins between uniform half-rate and sitespecific full-rate are very close to $30 \%$ infestation levels (Fig. 2). Considering the significant savings of herbicides in patch spraying strategy (71.2\%, Table 1) compared to uniform application throughout the field ( $50 \%$, Table 1 ), it could be justified to use sitespecific weed management in fields with less than $30 \%$ weed infestation, and half-rate uniform applications in fields with weed infestations ranging between 30 and $40.8 \%$.

In fields with a high proportion of infested area ( $>40.8 \%$ ), the low herbicide savings obtained did not justify the cost of sitespecific technologies. Indeed, the necessary technology to conduct patch spraying treatments (mainly mapping costs) cannot economically compensate the resulting costs of this management and, consequently, under this scenario the uniform application of full-rate herbicide is recommended. These results agree with previous research, which reports uniform management as the treatment that maximized total net returns compared to site-specific weed management (Wilkerson et al., 2004). This study pointed to the time and labour required for developing weed population maps as the primary constraint to adoption of site-specific weed management technology. In this sense, Rider et al. (2006) have proposed to improve weed detection methods to reduce the costs associated with site-specific weed management, making it feasible for more producers to adopt in the future.

Therefore, according to both the economic assessment and the herbicide savings, in the four examples in Fig. 1 should be applied the following strategies: in field $\mathrm{A}$, it would be recommended not applying any additional post-emergence herbicide; in fields $B$ and $C$ the recommended strategy would be site-specific herbicide application; and in field $\mathrm{D}$, the recommended treatment would be uniform over the whole-field using full-rates of herbicide.

As expected, the use of buffers did not result in any improvement in the economic benefits. However, these security areas may reduce the risks associated to patch displacement and to lack of spatial precision for weed detection and herbicide spraying. Although previous studies have shown the stability of the populations of some weed species (Wilson and Brain, 1991), in other cases differences have been found in the position of weed patches from year to year (Nordmeyer, 2006). In the specific case of S. halepense, previous studies have shown the relatively high spatial stability of this species (Andújar et al., 2011a).

\section{Conclusions}

In spite of the substantial reductions in herbicide use (and costs) derived from the use of site-specific weed management techniques, the improvements in final net returns are often minimal. Our study indicates that, once the added costs of weed detection, mapping and specific application technologies are considered, site-specific strategies only make economic sense for a relatively narrow window of S. halepense infested area (6.5-18.7\%). This ultimately might explain why farmers are often reluctant to adopt these new systems. However, S. halepense survey data show that $22 \%$ of the fields sampled were within this range. This proportion is significant and justifies further interest in these techniques. In addition, spillover benefits of the new technology are related to efficiencies in application that would have social benefits such as less herbicide out in the environment and the associated detrimental effects. Therefore, new regulations promoting a sustainable use of herbicides on the basis of environmental impact, consumer protection as well as traceability in the food production process, could encourage the adoption of these technologies by farmers.

\section{Acknowledgement}

This research was funded by the Spanish CICyT (project AGL 2008-04670-C03) and by the Alfonso Martin Escudero Foundation.

\section{References}

Andújar, D., Ribeiro, A., Fernández-Quintanilla, C., Dorado, J., 2011a. Reliability of a visual recognition system for detection of johnsongrass (Sorghum halepense) in corn. Weed Technol. 25, 645-651.

Andújar, D., Ruiz, D., Ribeiro, A., Fernández-Quintanilla, C., Dorado, J., 2011b. Spatial distribution patterns of johnsongrass (Sorghum halepense) in corn fields in Spain. Weed Sci. 59, 82-89.

Barroso, J., Fernández-Quintanilla, C., Maxwell, B.D., Rew, L.J., 2004. Simulating the effects of weed spatial pattern and resolution of mapping and spraying on economics of site-specific management. Weed Res. 44, 460-468. 
Barroso, J., San Martín, C., Andújar, D., Hernaiz, P., Campos, D., Martín, J.M., Dorado, J., 2011. Competencia entre la cañota (Sorghum halepense) y el maíz grano. In: Arévalo, J.R., Fernández, S., López-Granados, F., Recasens, J., Sobrino, E. (Eds.), XIII Congreso Nacional de Malherbología. Plantas Invasoras, Resistencia a Herbicidas y Detección de Malas Hierbas. Servicio de Publicaciones de la Universidad de La Laguna, La Laguna, Spain, pp. 183-186.

Gerhards, R., Christensen, S., 2003. Real-time weed detection, decision making and patch spraying in maize, sugarbeet, winter wheat and winter barley. Weed Res. 43, 385-392.

Gerhards, R., Oebel, H., 2006. Practical experiences with a system for site-specific weed control in arable crops using real-time image analysis and GPScontrolled patch spraying. Weed Res. 46, 185-193.

Gerhards, R., Sokefeld, M., 2003. Precision farming in weed control - system components and economic benefits. In: Stafford, J., Werner, A. (Eds.), Precision Agriculture, Proceedings of the 4th European Conference on Precision Agriculture. Wageningen Academic Publishers, Wageningen, The Netherlands, pp. 229-234.

Johnston, K., 2004. ArcGis 9: Using ArcGis Geostatistical Analyst. GIS by ESRI. Esri Press, Redlands, California.

Jordan, D.L., Wilkerson, G.G., Krueger, W., 2003. Evaluation of scouting methods in peanut (Arachis hypogaea) using theoretical net returns from HADSS $^{\mathrm{TM}}$. Weed Technol. 17, 358-365.

López-Granados, F., 2011. Weed detection for site-specific weed management: mapping and real-time approaches. Weed Res. 51,1-11.

Lutman, P.J.W., Miller, P.C.H., 2007. Spatially Variable Herbicide Application Technology; Opportunities for Herbicide Minimisation and Protection of Beneficial Weeds. In: Research Review No 62. Home-Grown Cereals Authority, London.
Nordmeyer, H., 2006. Patchy weed distribution and site-specific weed control in winter cereals. Precis. Agric. 7, 219-231.

Rider, T.W., Vogel, J.W., Dille, J., Dhuyvetter, K.C., Kastens, T.L., 2006. An economic evaluation of site-specific herbicide application. Precis. Agric. 7, 379-392.

Ruiz, D., Escribano, C., Fernández-Quintanilla, C., 2006. Assessing the opportunity for site-specific management of Avena sterilis in winter barley fields in Spain. Weed Res. 46, 379-387.

Swinton, S.M., 2005. Economics of site-specific weed management. Weed Sci. 53, 259-263.

Taberner, A., 2006. Report of the XXV meeting of the "weeds and herbicides" working group. In: Ministerio de Agricultura Pesca y Alimentación - MAPA (Ed.), Reuniones Anuales de los Grupos de Trabajo Fitosanitarios 2006. MAPA Centro de Publicaciones, Madrid, Spain, pp. 285-304.

Timmermann, C., Gerhards, R., Kuehbauch, W., 2003. The economic impact of the site specific weed control. Precis. Agric. 4, 241-252.

Van Wychen, L.R., Luschei, E.C., Bussan, A.J., Maxwell, B.D., 2002. Accuracy and cost effectiveness of GPS-assisted wild oat mapping in spring cereal crops. Weed Sci. 50, 120-129.

Weis, M., Gutjahr, C., Rueda-Ayala, V., Gerhards, R., Ritter, C., Schölderle, F., 2008. Precision farming for weed management: techniques. Gesunde Pflanz 60, 171-181.

Wilkerson, G.G., Price, A.J., Bennett, A.C., Krueger, D.W., Roberson, G.T., Robinson, B.L., 2004. Evaluating the potential for site-specific herbicide application in soybean. Weed Technol. 18, 1101-1110.

Wilson, B.S., Brain, P., 1991. Long term stability of Alopecurus myosuroides within cereal fields. Weed Res. 31, 367-373.

Young, D.L., Kwon, T.J., Smith, E.G., Young, F.L., 2003. Site-specific herbicide decision model to maximize profit in winter cereals. Precis. Agric. 4, 227-238. 